\title{
Groundwater Vulnerability Assessment using Drastic Index and GIS in Kumasi Metropolitan Assembly, Ghana*
}

\author{
A. Ewusi, A. Asante-Annor, J. Seidu and L. O. Gyeabour
}

Ewusi, A., Asante-Annor, A., Seidu, J., and Fosu-Gyeabour, L. O. (2016) "Groundwater Vulnerability Assessment using Drastic Index and GIS in Kumasi Metropolitan Assembly, Ghana”, Ghana Mining Journal, Vol. 16, No. 1, pp. 21 - 30.

\begin{abstract}
The assessment of groundwater vulnerability to contamination has become an important element for landuse planning and groundwater resource management. This study aims at estimating groundwater vulnerability using an integration of Geographic Information System (GIS) and DRASTIC method in the Kumasi Metropolitan Assembly (KMA). The groundwater vulnerability map was prepared using index and overlay analysis with the aid of Arc GIS 10. The DRASTIC Index (DI) computed ranged between 70 and 164 as the lowest and highest contamination potential respectively. The eastern and western flanks and north-west tip of KMA are underlain by the granites which bear water due to the combined effect of weathering and fracturing and are dominated by "Very High", "High" and "Moderate" vulnerability based on the vulnerability index computed. The "Low" and "Very Low" vulnerability are located at the northern, central and southern parts of KMA which are underlain by phyllites. These suggest that boreholes located in the Birimian metasedimentary units which comprise mainly phyllites would be less likely to be vulnerable to contamination than those located in the intrusive rocks dominated by the granites.
\end{abstract}

Keywords: Groundwater Vulnerability, Soil Media, Hydraulic Conductivity, Overlay Analysis

\section{Introduction}

Kumasi is the second largest city in Ghana, located in the south-central part of Ghana. It is an industrial, commercial and cultural city with rapidly increasing population due to its unique position and road networks. According to (Anon., 2009) total treated water demand is $304000 \mathrm{~m}^{3}$ per day $\left(\mathrm{m}^{3} / \mathrm{d}\right)$. The Water Supply System (WSS) is able to supply $123000 \mathrm{~m}^{3} / \mathrm{d}$ and this leaves a deficit of $181000 \mathrm{~m}^{3} / \mathrm{d}$. Groundwater is therefore the available efficient and cost effective alternate source to supplement this demand (Kuma et al., 2010). However, the limited groundwater resource is prone to contamination as a result of the increased numerous anthropogenic activities in the area. There is therefore the need to assess the vulnerability to contamination of the groundwater in the area since this can limit its use. This study seeks to produce a vulnerability map to show the areas which are susceptible to contamination.

\subsection{Location and Accessibility}

Kumasi is located about $300 \mathrm{~km}$ north-west of Accra. Kumasi Metropolitan Assembly (KMA) covers an area of $245 \mathrm{~km}^{2}$ and can be accessed through several regions in Ghana (Fig 1). KMA has a population of about two million, and thirty-five thousand, and sixty-four (2 035064$)$ inhabitants (Anon., 2010).

\subsection{Topography and Climate}

Generally, topography of KMA is undulating with gentle slopes that range between $50 \mathrm{~m}$ and $150 \mathrm{~m}$.
Kumasi lies on top of a local watershed which is approximately $282 \mathrm{~m}$ high (Nsiah-Gyabaa, 2000). The altitude in the peri-urban interface around KMA ranges between $250 \mathrm{~m}$ and $300 \mathrm{~m}$ high (Holland et al., 1996). The granitic areas are slightly hilly and the interfluves ridges are flat topped with varying widths. The landform is an advanced dissection of a tertiary erosion surfaces (Holland et al., 1996).

Kumasi lies within the moist semi-humid climate zone of Ghana and experiences two rainfall seasons. The first rainy season starts from March to July and the second season starts from August to October. The peak rainfall occurs in the months of June and September with their average annual rainfall is $217.7 \mathrm{~mm}$ and $218.6 \mathrm{~mm}$ respectively (Anon., 2012). September had been the wettest month for the last 32 years. The periods between November and early March are the dry season. Average annual rainfall recorded between 1980 and 2012 is $1385.35 \mathrm{~mm}$.

\subsection{Soil Resources}

The soils in the KMA is grouped under Forest Ochrosol great group (Holland et al, 1996). Initially very high in organic matter but intensive agriculture has considerably reduced the organic matter to very low levels in some areas. Soils developed on the granites are quite acidic whereas those on the phyllites are less acidic and the dominant textures are sandy loams (Anon., 1999).

*Manuscript received September 30, 2015

Revised version accepted June 6, 2016

http://dx.doi.org/10.4314/gmj.v16i1.3 


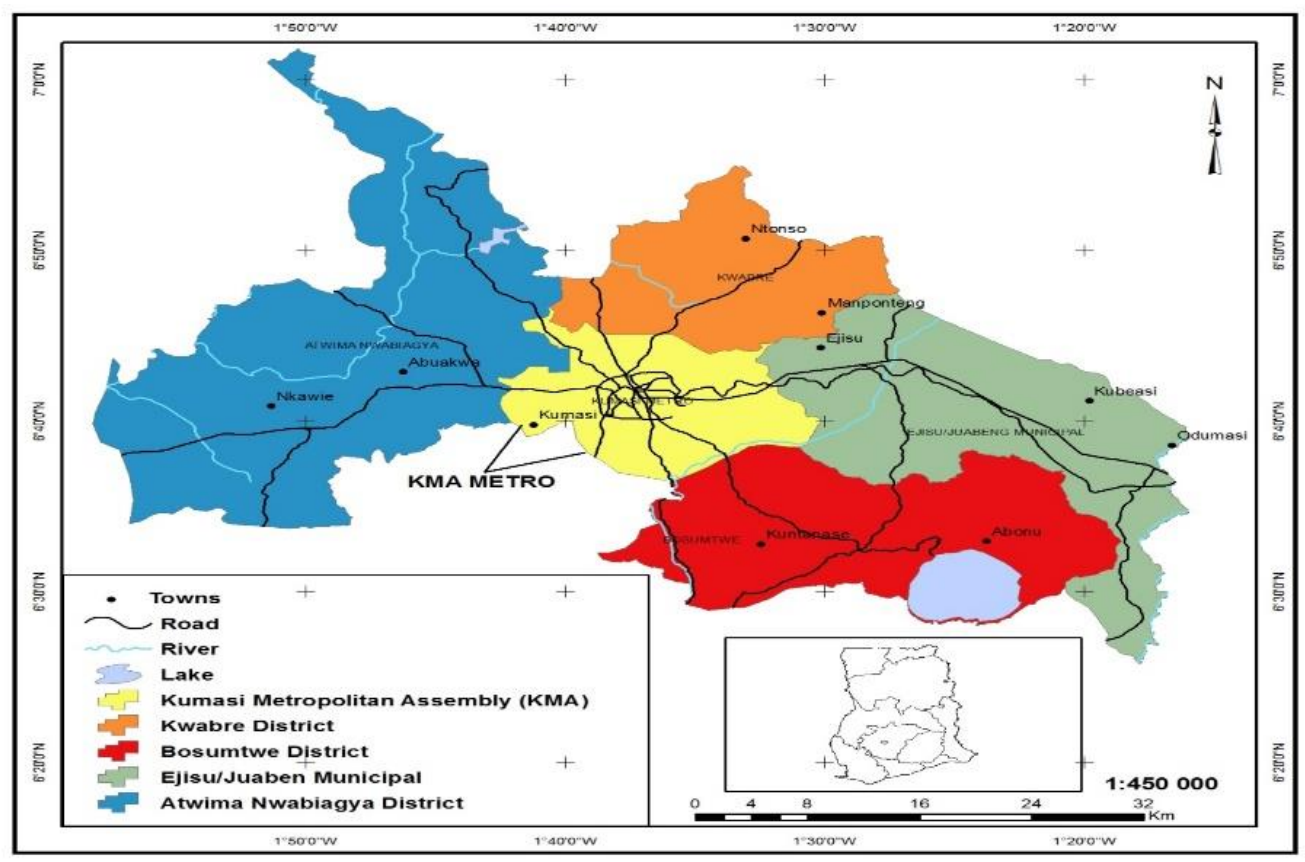

Fig. 1 Location Map of Kumasi Metropolitan Assembly KMA

\subsection{Drainage of KMA}

The Metropolis is located within the Pra River Basin (Dickson and Benneh, 1988). The drainage in KMA consists of a network of streams which run naturally from north to south in a relatively dense pattern. They include major streams; Daban, Wiwi, Subin, Aboabo and Santang. They show dentritic patterns and stem out of the Sisa, Oda, Sokoban and Owabi rivers which have flat bottom valleys (Dickson and Benneh, 1988). Rivers Wiwi, Daban and Subin flow into River Sisa which also drains into River Oda.

The streams and run-off from the north west of KMA, where the vehicle repair area popularly known as "magazine" is located, drain north west into the catchments of River Owabi. River Owabi then flows into the River Offin (Cornish and Aidoo, 1999).

\subsection{Local Geology}

The Kumasi Metropolis is underlain by two main geological formations. The Birimian metasedimentary units (of Precambrian origin) and the batholiths which are slightly younger of acid intrusive rocks (Murray et al., 1960).

The Birimian metasedimentary units consist of dark grey slaty phyllites, phyllites, tuffaceous phyllites (ash) and greywackes. Gradations between these exist and different rock types are often interbedded. The greywackes vary from fine to medium grained and all have been metamorphosed and recrystallised. Near the contact with the intrusives metamorphism has produced biotite, staurolite, garnet and kyanite schist. The rocks are deeply weathered and fresh outcrops of phyllites are rare. Quartz veins intrude the phyllites and thus occur all over the area underlain by the Birimian metasedimentary units. They generally follow the strike and dip of the phyllites and occur in the NE-SW trend. They also occur around large xenoliths in the granite east of Senfi on the Kumasi-Takoradi railway line. Quartz veins are the most common with mica and tourmaline, indicating a relation with the pegmatite. Pegmatite dykes occur around the edges of the granite (Murray et al., 1960). The intrusive rocks consist of variations of textural granitic rocks, (mainly the Cape Coast granite which is also referred to as the basin type granitoid). It is made up of granite, muscovitegranite, biotite-granite, granodiorite, aplite and boitite schist pendants and may be cut by pegmatite (Gogo, 1990). Accordingly, Gogo (1990) found out that the granites occur in large batholiths and as small masses that have usually intruded the Birimian metasedimentary rocks (Fig. 2). The biotite-rich muscovite granites of Kumasi are foliated though not marked in places. However, due to the variations in intensity of metamorphism in these granitic rocks, their texture and composition range from those of typical granites to granitic gneiss (Gogo, 1990). 


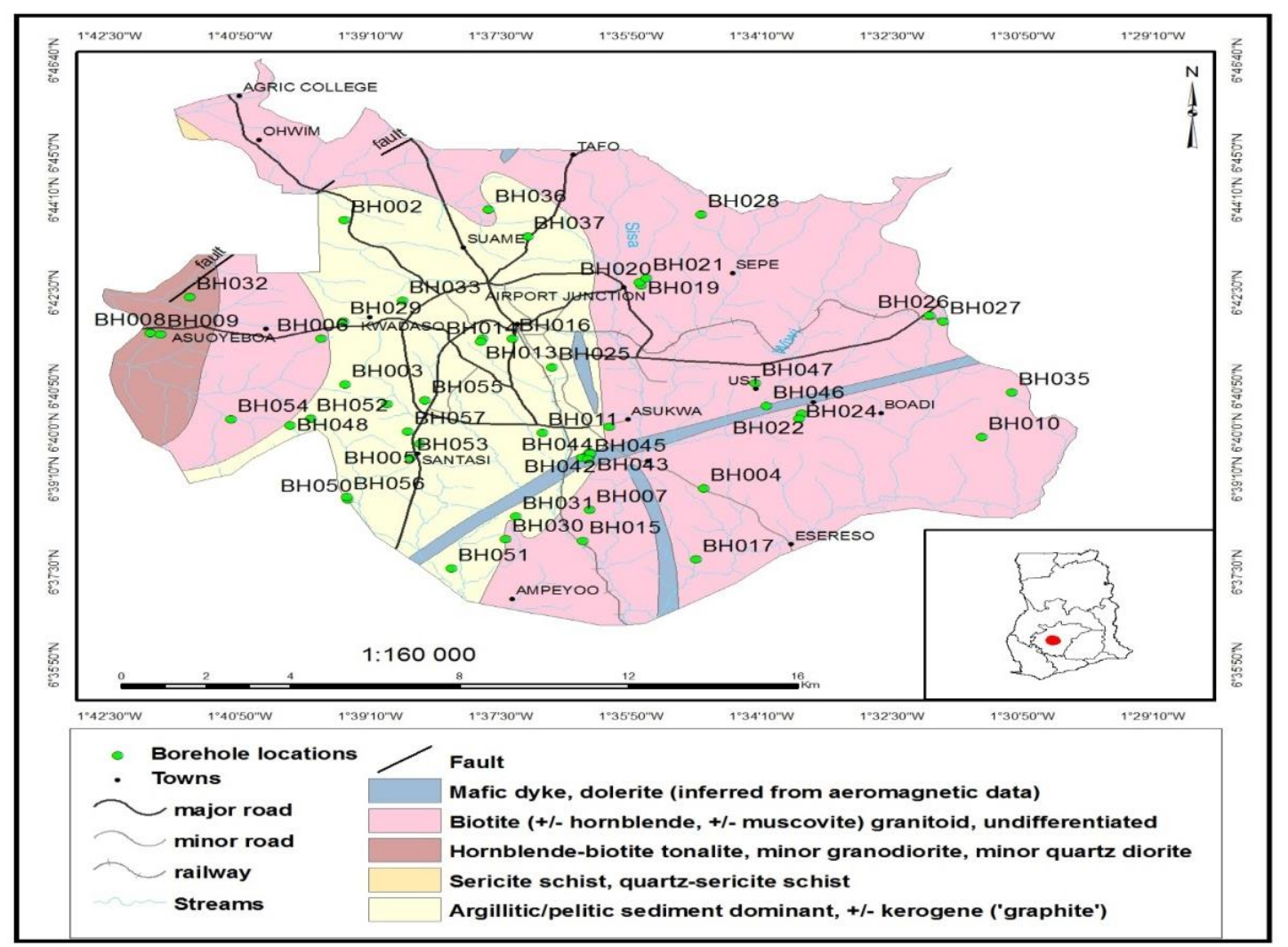

Fig. 2 Geological Map of KMA (modified after Murray et al., 1960)

\subsection{Hydrogeology of KMA}

The Birimian rock units are generally strongly foliated, jointed and fractured, and where they outcrop, considerable amount of water may flow through the joints, fractures, foliation and bedding planes (Kesse, 1985).This shows that, though the intrusive (granitic rock) that is associated with Birimian rocks have no primary permeability because it is massive. Secondary permeability has developed as a result of some deformation through jointing, fracturing and weathering. These deformations have contributed to the relatively averagely higher yields of groundwater found in the boreholes within KMA (Kesse, 1985).

The deepest borehole was recorded as $62.5 \mathrm{~m}$ depth located in the phyllites whilst the shallowest borehole with a depth of $21 \mathrm{~m}$ is located in the granites. An average depth of $40.32 \mathrm{~m}$ is recorded over 80 boreholes. The highest aquifer width is 26 $\mathrm{m}$ and the lowest is $3 \mathrm{~m}$ with an average aquifer width of $11.38 \mathrm{~m}$. The deepest aquifer occurred between $55 \mathrm{~m}$ and $61 \mathrm{~m}$ and the shallowest between $6 \mathrm{~m}$ and $18 \mathrm{~m}$. The maximum yield recorded is 900 litres per minute $(1 / \mathrm{m})$ and minimum of $8 \mathrm{l} / \mathrm{m}$. General observations made are that, boreholes that are located in the phyllites have higher yields than those located in the granites. The phyllites of the metasedimentary units have higher permeability due to its secondary porosities developed into fractures by the cleavage or foliation planes (Fetter, 1994). The granite which is an intrusive unit has a lower permeability.

\section{Resources and Methods Used}

Both primary and secondary data sources were used. The primary data was obtained by using a handheld Global Position System (GPS) to map some contaminant sources in the study area. The secondary data were obtained from various sources including Ghana Water Company (GWC), Ghana Meteorological Agency (GMA) and Council for Scientific and Industrial Research (CSIR).

The data extracted from the various data sets were compliled into a spread sheet using Microsoft Excel. This was then converted into a shapefile in Arc GIS Arc Info 10 suite mostly as point attributes. The DRASTIC method is an acronym which incorporate seven parameters of the hydrogeological and physical characteristics of an area. The seven parameters include; depth to water, net recharge, aquifer media, soil media, topography, impact of vadose zone and hydraulic conductivity.

\subsection{Creation of the seven DRASTIC Parameters using Arc GIS 10}

Arc Info 10 from Arc GIS software was used to create layers for each of the seven DRASTIC parameters using Gostatistical Analyst Tool from 
the Arc GIS through interpolation (using Kriging and Co-Kriging) to create vector surface layer. This was then converted to raster surface layer through classification, where the ratings were assigned to the parameters. The classified raster layer was converted into reclassify raster layer under the Spatial Analyst Tools and this was used for overlay analysis.

\subsection{Overlay Analysis of the Seven DRASTIC Parameters}

After obtaining the reclassified raster layers for each of the seven DRASTIC parameters, Arc GIS 10 suite was used to overlay all the raster layers by Spatial Analyst Tools under Overlay and then the Weighted Overlay. With the DRASTIC method, the rating of each parameter is multiplied by its weight assigned and all the seven DRASTIC parameters are summed up to obtain the DRASTIC Indices. The weighted overlay in Arc GIS 10 and all the reclassified raster layers were overlaid and the percentage influence was inserted. The field values (1, 2, 3, 4, and 5) indicate increasing order of vulnerability selected and scale value which represents the degree at which the parameter is influencing the vulnerability.

\section{Results and Discussion}

Table 1 summarises results of DRASTIC parameters constructed from the datasets for GIS processes to create the layers and subsequent overlay of the layers to produce the Groundwater Vulnerability Map (GVM) of KMA. A summary of the application of GIS is illustrated in Fig. 3.

Contaminant sources such as waste dump, land fill, sawmills, abattoir, cemeteries and garages from the mapping carried out with the handheld GPS is illustrated in Fig 4.

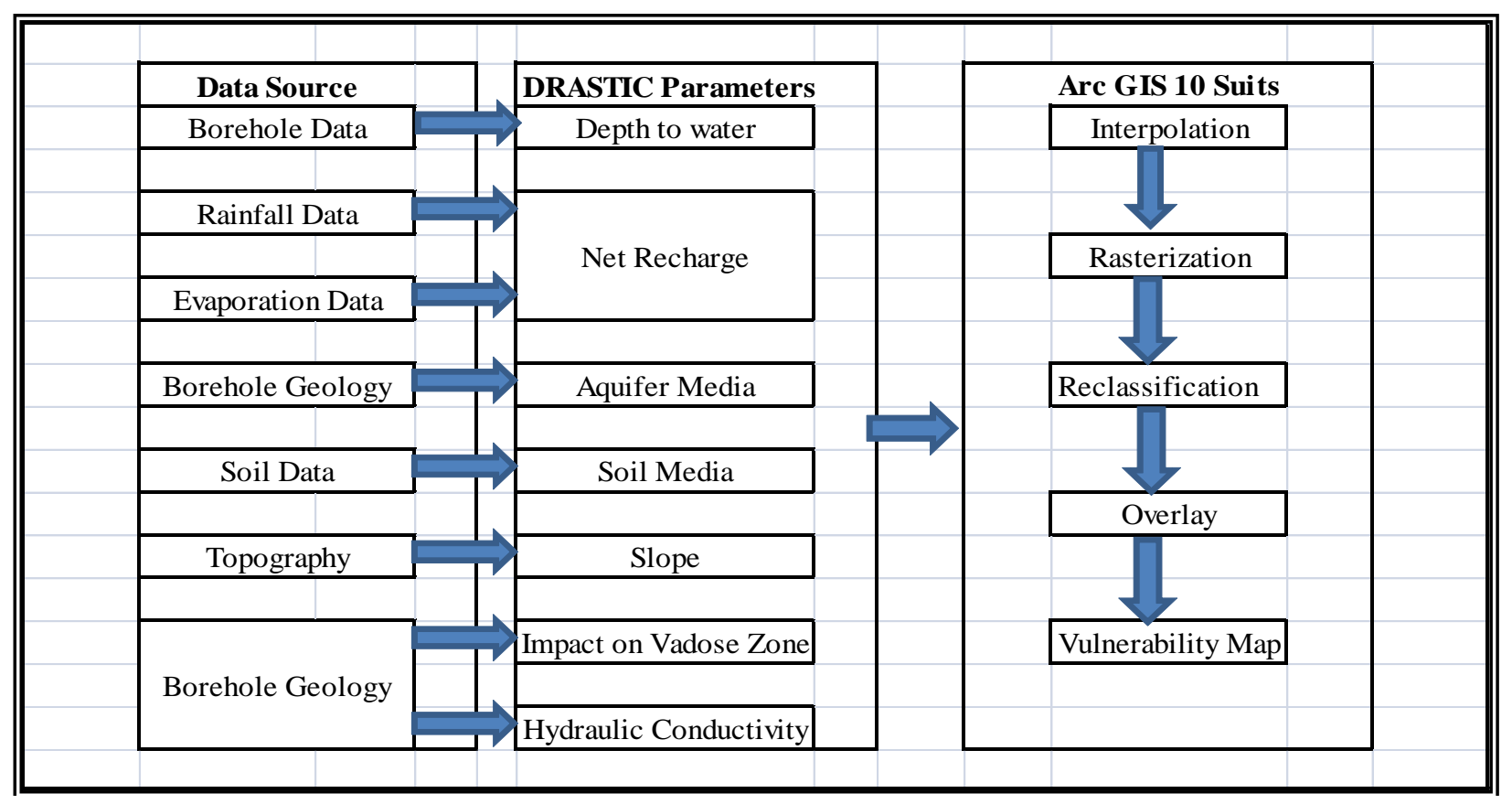

Fig. 3 Flow Chart of Arc GIS Arc Info 10 MethodsUsed

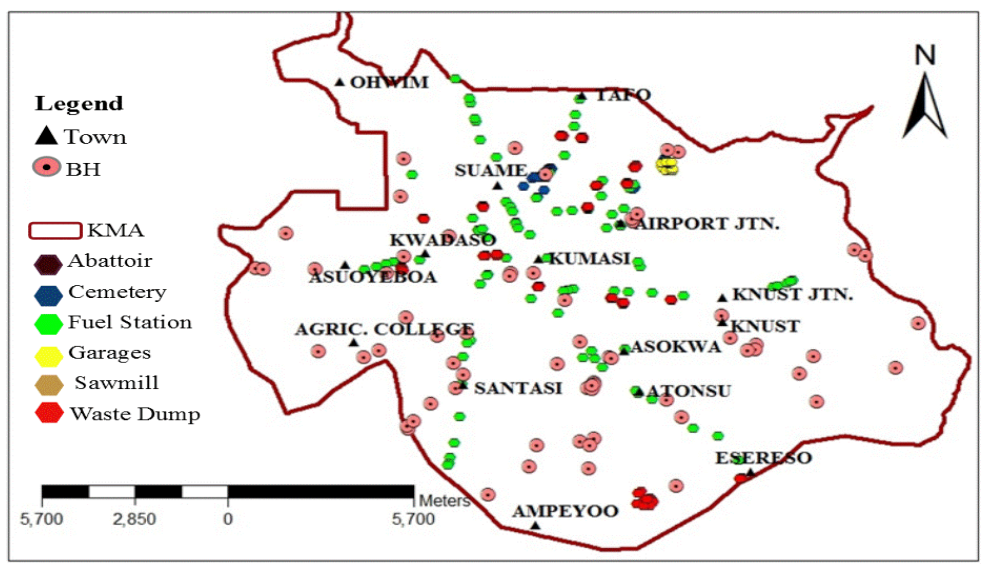

Fig. 4 Map Showing Contaminant Sources in KMA 
Table 1 DRASTIC Parameters Extracted from the Datasets

\begin{tabular}{|c|c|c|c|c|}
\hline DRASTIC Parameter & Range / Types & Code & Rating & Weight \\
\hline \multirow[t]{5}{*}{ Depth to Groundwater (m) } & $0-1.5$ & & 10 & \multirow{5}{*}{5} \\
\hline & $1.5-4.6$ & & 9 & \\
\hline & $4.6-9.1$ & & 7 & \\
\hline & $9.1-15.2$ & & 5 & \\
\hline & $15.2-22.9$ & & 3 & \\
\hline \multirow[t]{5}{*}{ Net Recharge (mm/year) } & $0.0-50.8$ & & 2 & \multirow{5}{*}{4} \\
\hline & $50.8-101.6$ & & 3 & \\
\hline & $101.6-177.8$ & & 5 & \\
\hline & $177.8-254.0$ & & 8 & \\
\hline & +254.0 & & 10 & \\
\hline \multirow[t]{4}{*}{ Aquifer Media } & fresh granite & 1 & 2 & \multirow{4}{*}{3} \\
\hline & fresh phyllite & 2 & 3 & \\
\hline & weathered phyllite & 3 & 4 & \\
\hline & weathered granite & 4 & 5 & \\
\hline \multirow[t]{4}{*}{ Soil Media } & clay & 1 & 3 & \multirow{4}{*}{2} \\
\hline & silt & 2 & 4 & \\
\hline & laterite & 3 & 6 & \\
\hline & sand & 4 & 9 & \\
\hline \multirow[t]{5}{*}{ Topography (Slope - \%) } & $0.0-1.0$ & & 10 & \multirow{5}{*}{1} \\
\hline & $1.0-2.0$ & & 9 & \\
\hline & $2.0-3.0$ & & 8 & \\
\hline & $3.0-4.0$ & & 7 & \\
\hline & $4.0-5.0$ & & 6 & \\
\hline \multirow[t]{5}{*}{ Impact of Vadose Zone } & clay & 1 & 2 & \multirow{5}{*}{5} \\
\hline & silt/mudstone & 2 & 3 & \\
\hline & phyllite & 3 & 4 & \\
\hline & granite & 4 & 4 & \\
\hline & sand & 5 & 8 & \\
\hline \multirow[t]{5}{*}{ Hydraulic Conductivity (m/day) } & $0.03-0.69$ & & 1 & \multirow{5}{*}{3} \\
\hline & $0.69-1.35$ & & 2 & \\
\hline & $1.35-2.02$ & & 3 & \\
\hline & $2.02-2.68$ & & 4 & \\
\hline & $2.68-3.34$ & & 5 & \\
\hline
\end{tabular}

\subsection{Depth to Groundwater}

Deeper water table levels imply lesser chance of a contaminant to get to the groundwater and vice versa. According to the DRASTIC assumptions, the contaminant is soluble in water and flows with it and is introduced on the surface of the earth. Therefore, if a contaminant is introduced, the boreholes with shallow depth to water table levels are more vulnerable to contamination than those with deeper depth water table levels. The eastern and western flanks of KMA are characterised by "Very High" and "High" vulnerability to contamination (Fig. 5). This implies that, boreholes drilled in the area intercepted the aquifer at shallow depths to water table suggesting less travel time for a contaminant to get to groundwater and more vulnerable to contamination. The dominant classes of vulnerability are the "Moderate" and "Low" vulnerability except at the southern part and small patches at the central and north where "Very Low" vulnerability occurred.

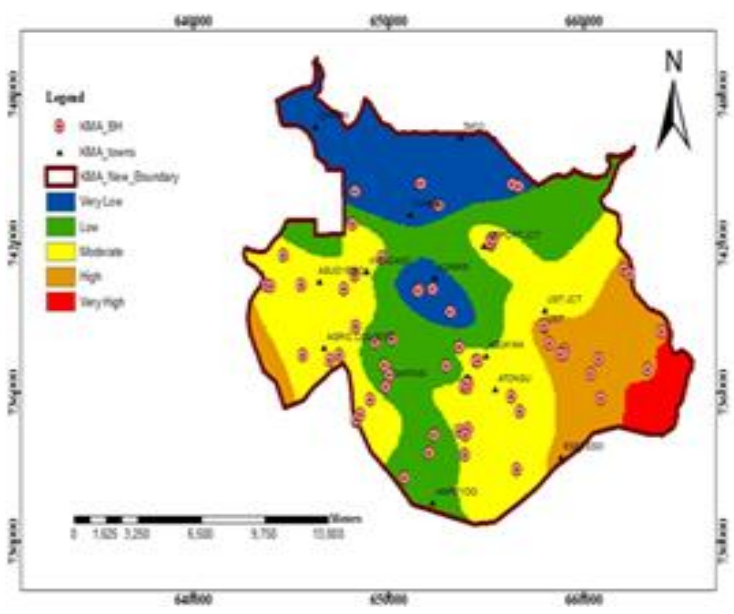

Fig. 5 Map of Depth to Groundwater Table Reclassified Raster of KMA

\subsection{The Net Recharge}

The net recharge represents the amount of water which percolates from the surface to reach the groundwater. Recharge water is the vehicle for 
transporting pollutants. Although the study area is characterised by relatively high annual rainfall (1 $377 \mathrm{~mm}$ per year), the net recharge to the groundwater aquifer is controlled by the type of landuse or landuse cover. The area is a metropolis which is associated with roof tops, pavements, tarred roads and car parks that prevent the penetration of available rainfall into groundwater.

High net recharge correspond to high vulnerability and the vice versa. The "Very High" and "High" vulnerability classes occurred at the south-eastern part and a small portion at the south-western parts (Fig. 6). These indicate that, there is more pervious surfaces for water with contaminant to percolate to the groundwater. The southern, western and northeast parts of KMA is characterised by "Moderate" vulnerability (Fig. 6) which indicates that, there is moderate pervious surfaces for water with contaminant to percolate. The northern, central and some portion of the southern parts of KMA are characterised by "Low" and "Very Low" vulnerability classes indicating more impervious surfaces and hence less water with contaminant to get to groundwater.

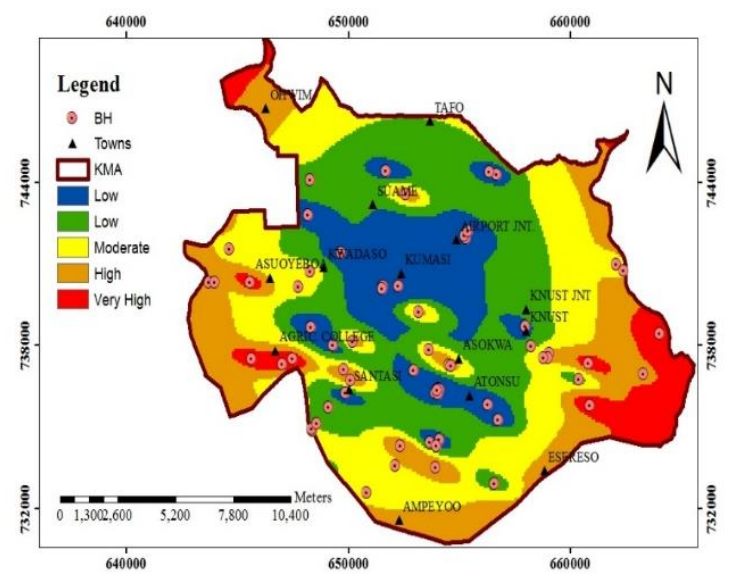

Fig. 6 Map of Net Recharge Reclassified Raster of KMA

\subsection{Aquifer Media}

The aquifer media refers to the unconsolidated or consolidated rock that serves as an aquifer. The larger the grain size and the more fractures within the aquifer, the higher the permeability and hence higher the vulnerability to contamination. Both fresh phyllites and fresh granites have low porosity (Fetter, 1994). Few pores present are generally not interconnected and therefore have low permeability. Phyllites and granites can bear water because of their secondary porosity that results from weathering, fracturing and shearing etc. Fresh fractured phyllites are more permeable than fresh fractured granites because of the foliation properties of phyllites compared to the massive texture of the granites. However, weathered granites would be more permeable than weathered phyllites because the weathering product of granites are predominantly sand which has a higher draining capability than silt and clay which results from the weathering of phyllites. The vulnerability classes of "Very High", "High" and "Moderate" occurring at the northern and eastern parts of KMA (Fig. 7) is underlain by weathered granites which has a higher permeability and hence highly vulnerable to contamination.

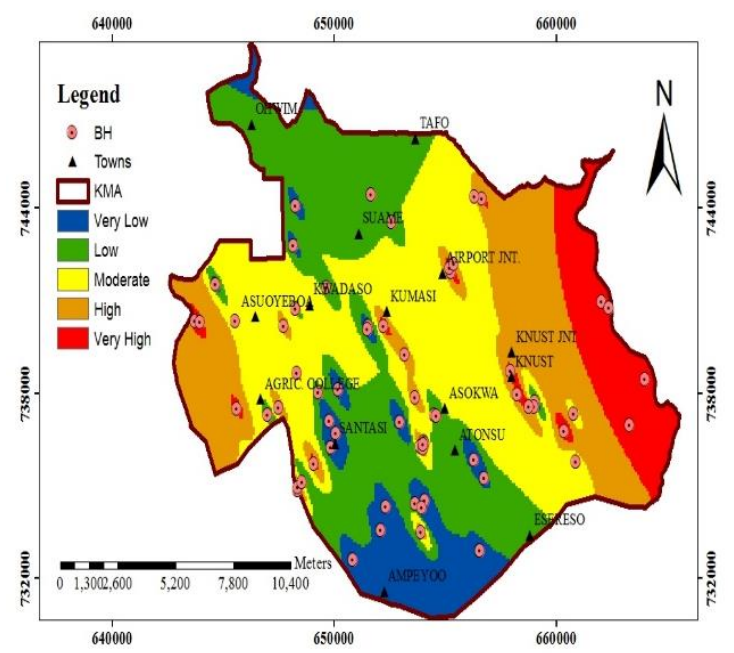

Fig.7 Map of Aquifer Media Reclassified Raster of KMA

The central, southern and western parts of KMA which are characterised by vulnerability classes of "Low" and "Very Low" are underlain by the fresh fractured granites and phyllites. Fresh fractured phyllites is more permeable than fresh fractured granites.

\subsection{Soil Media}

The soil media is the upper weathered section of the earth. The most predominant soils are clay, silt, laterite and sand. Sandy materials have grain sizes larger than silty materials and as a result the draining ability of sandy materials are more than the silty materials which are finer. In the DRASTIC model, the higher the draining capability of the soil, the higher the vulnerability. Therefore, the degree of increasing vulnerability would be as follows; sand, laterite, silt and clay. Hence areas with sandy materials were assigned highest rate and the clayey lower rates. A map produced using the soil media (Fig. 8) shows that, the area is predominantly characterised by "Low" and "Very Low" vulnerability except at the southeast corner and north-west tip of KMA where it is characterised by "moderate" and "high" vulnerability. The rock units at this corner are granites, which are most likely weathered into sand. The sand has more draining capability than the other soil textures in KMA. 


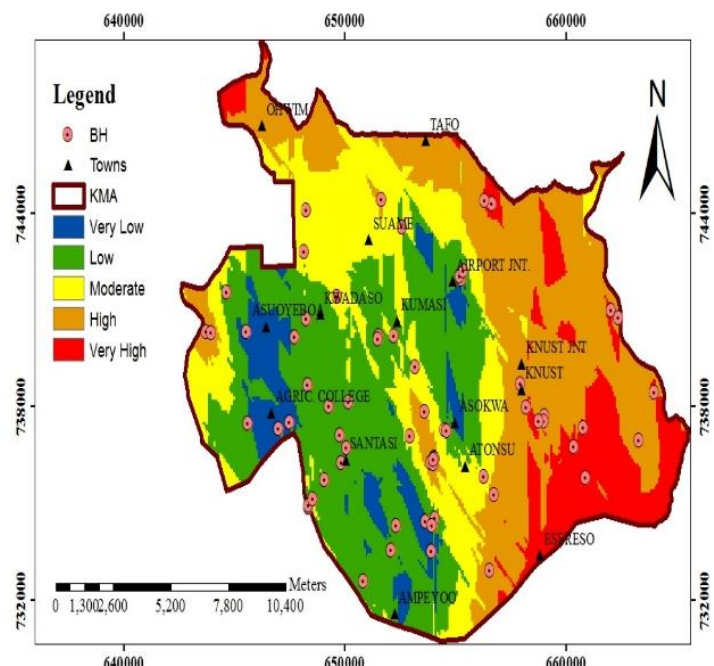

Fig. 8 Map of Soil Media Reclassified Raster in KMA

\subsection{Topography (Slope percentage)}

In the DRASTIC method, high slope percentages increase the run-off and thereby decreasing vulnerability. The low percentage slope indicates a decrease in run-off and the subsequent retention of contaminant and hence high vulnerability.

The vulnerability classes of "Very High" and "High" are characterised by low slope percentages and occur at the south-east, north-west, north-east, south and west parts of KMA. The "Moderate", "Low" and "Very Low" vulnerability classes occur at the central section of KMA representing an increasing order of slope percentages in KMA (Fig. 9).

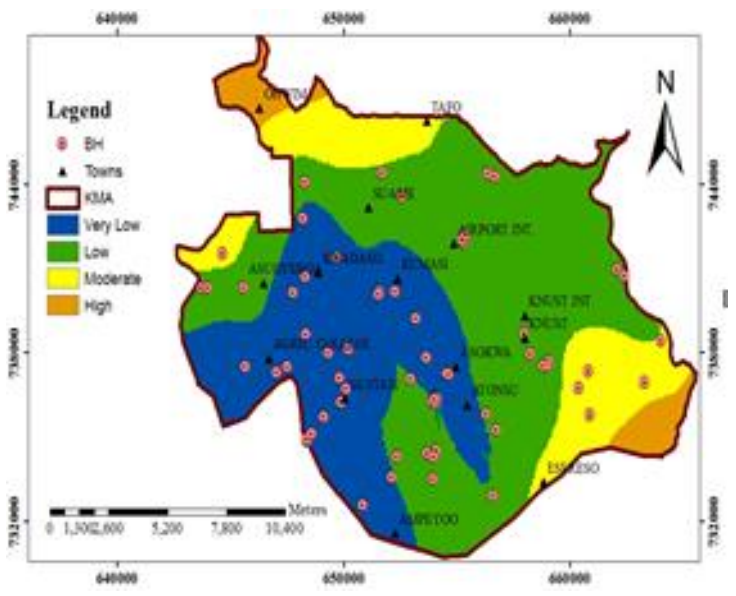

Fig. 9 Map of Topography Reclassified Raster of KMA

\subsection{Impact of Vadose Zone}

The texture of the vadose zone determines the travel time of the contaminant. In the DRASTIC model, the ability of the vadose zone material to hold water with contaminant has the low contamination potential. The higher the material to allow water with the contaminant to seep through it, the higher the vulnerability to contamination. It was generally observed that, the vadose zone of the study area occurred in the weathered zones. The decreasing order of vulnerability is sand, granites, phyllites, siltstone and clay.

The "Very High" and "High" vulnerability classes which occur at the east, west, south-east, northwest and north-east sections of KMA are underlain by the granites. The weathering product of the granites are mostly sand which has a high draining ability and hence highly vulnerable (Fig. 10). The "Moderate", "Low" and "Very Low" vulnerability classes which occur at the west, east, south, northeast and northern parts of KMA are underlain by phyllites (Fig. 10). The weathering product of phyllites is silt and clay which has a low draining abilities and therefore allow less water to seep through.

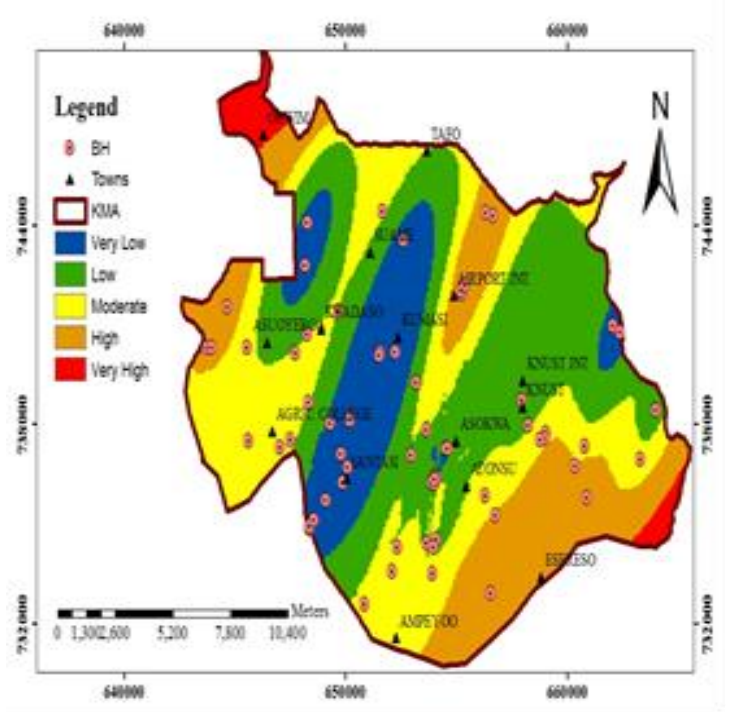

Fig. 10 Map of Impact of Vadose Zone Reclassified Raster of KMA

\subsection{Hydraulic Conductivity}

The hydraulic conductivity in the study area ranged between $0.03 \mathrm{~m} /$ day and $3.34 \mathrm{~m} /$ day. This parameter is the measure of permeability. Therefore, the higher the hydraulic conductivity, the higher the vulnerability to contamination.

Hydraulic conductivity in the weathered granites are higher than the weathered phyllites. This is because, the weathering product of granites is predominantly sand which has a higher permeability than phyllites because weathering products are predominantly clay and silt. Fracturing in the fresh phyllites is more intense than in the fresh granites as a result of the structural properties (such as foliation and bedding). Moreover, there is an existence of carbonate alterations in fresh 
phyllites than in fresh granites (Perrouty et al., 2012). These carbonate minerals are subject to relatively rapid solution by the circulating groundwater thereby increasing the size of the fractures and increasing permeability within the aquifer media. Therefore, the hydraulic conductivity of the boreholes in the fresh phyllites are higher than those drilled in the fresh granite. The results of intense weathering and the resulting hydraulic conductivity computed in the area is indicated in Fig. 11. This also suggest that higher hydraulic conductivity gives higher vulnerability. The phyllites which occupy the central part of KMA has vulnerability zones of "Very Low", and "Low" whilst the granites which occupy the northern, eastern, western and southern parts of KMA have "Moderate", "High" and "Very High" vulnerability.

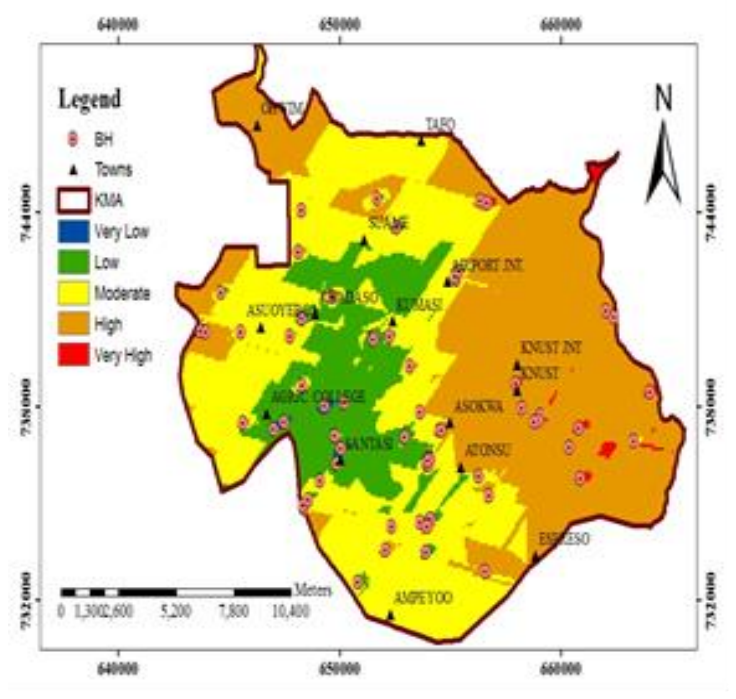

Fig. 11 Map of Hydraulic Conductivity Reclassified Raster of KMA

\subsection{DRASTIC Index (DI) Determination}

The determination of DRASTIC Index (DI) of each of the eighty boreholes were carried out using the seven parameters of the DRASTIC Method. It was obtained by multiplying the parameter ratings by its weight and summation of all the seven parameters. This is expressed mathematically as:

$\mathrm{DI}=\mathrm{D}_{\mathrm{r}} \mathrm{D}_{\mathrm{w}}+\mathrm{R}_{\mathrm{f}} \mathrm{R}_{\mathrm{w}}+\mathrm{A}_{\mathrm{f}} \mathrm{A}_{\mathrm{W}}+\mathrm{S}_{\mathrm{r}} \mathrm{S}_{\mathrm{w}}+\mathrm{T}_{\mathrm{r}} \mathrm{T}_{\mathrm{w}}$

where $r$ and $w$ are the DRASTIC parameter ratings and weights respectively.

The DI calculated for a DRASTIC Model ranged between 70 and 164 as lowest and highest respectively. The higher the DI, the more susceptible the area is to contamination. However, a lower DI does not necessarily mean no contamination can occur, but it would be less susceptible to contamination.

Table 2 summarises the DI values obtained for the area into its various classifications. It is observed that, the predominant vulnerability zone is "Low" which occupies $51.22 \%$ of the total area. It is followed by the classes of "Moderate" and "High", with $32.86 \%$ and $7.54 \%$, coverage of the area respectively. Areas of "Very Low" and "Very High" are very small and occupy $6.14 \%$ and 2.24 $\%$ coverage of the total area respectively.

\subsection{Overlay Analysis of the DRASTIC Parameters}

GIS Arc Map - Arc Info was used to overlay the seven DRASTIC raster layers to produce the Groundwater Vulnerability Map of KMA as illustrated in Fig. 12.

The Groundwater Vulnerability Map (GVM) shows that, "Very Low" and "Low" vulnerability classes occur on the northern, central and southern parts of KMA (Fig. 12). These vulnerability classes have DI that ranged from 70 to 89 and 89 to 108 respectively. They cover an area of $14.64 \mathrm{~km}^{2}$ or $6.14 \%$ and $122.21 \mathrm{~km}^{2}(51.22 \%)$ of the total area of KMA respectively (Table 2). "Moderate" and "High" vulnerability classes occur at the eastern and western flanks and north-west tip of KMA (Fig.13). They have DI which ranged from 108 to 127 and from 127 to 146 respectively. They cover an area of $78.40 \mathrm{~km}^{2}(32.86 \%)$ and $17.99 \mathrm{~km}^{2}$ $(7.54 \%)$ respectively, of the total area of KMA respectively (Table 2). The "Very High" vulnerability class occur at the south-east part of KMA, (Fig.13). It has a DI that is ranged from 146 to 164 ; covers an area of $5.34 \mathrm{~km}^{2}(2.24 \%)$ of the total area of KMA (Table 2).

Table 2 DI Range, Area and Percentage Area of Vulnerability.

\begin{tabular}{|c|c|c|c|c|c|c|}
\hline \multirow{2}{*}{ Class Number } & \multirow{2}{*}{ Classification } & \multicolumn{3}{|c|}{ Range (DI) } & \multirow{2}{*}{ Area $\left(\mathbf{k m}^{\mathbf{2}}\right)$} & \multirow{2}{*}{ Area covered $(\boldsymbol{\%})$} \\
\cline { 3 - 5 } & & From & To & Interval & & 6.14 \\
\hline 1 & Very Low & 70 & 89 & 19 & 14.64 & 51.22 \\
\hline 2 & Low & 89 & 108 & 19 & 122.21 & 32.86 \\
\hline 4 & Moderate & 108 & 127 & 19 & 78.40 & 7.54 \\
\hline 5 & High & 127 & 146 & 19 & 17.99 & 2.24 \\
\hline
\end{tabular}




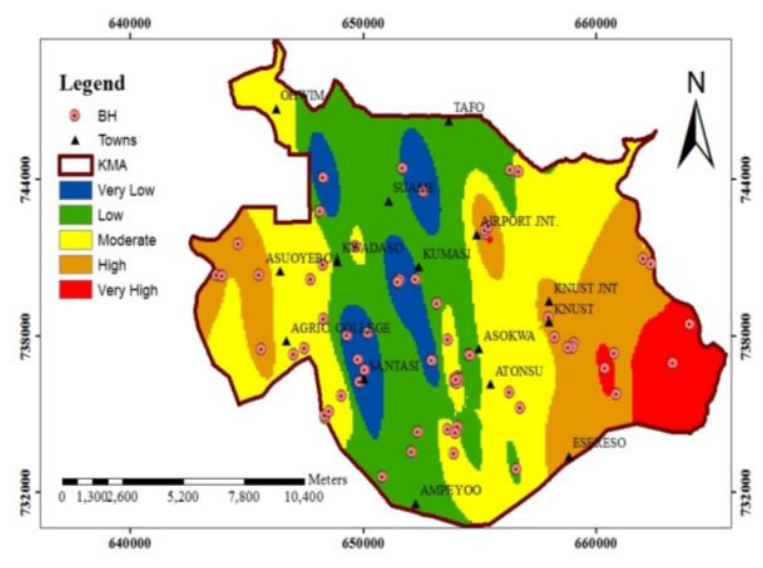

Fig. 12 Groundwater Vulnerability Map of KMA

The vulnerable zones characterised by "Very Low" and "Low" are mainly dictated by the geology of the area. The rock units in these vulnerable zones are predominantly phyllites. The type of rock units affect the soil media, vadose zone impact, the aquifer media and the hydraulic conductivity. The primary porosity of fresh phyllites is very low. However they are able to bear water because of fractures and weathering. The vodose zone was observed to have been mostly silt and clay, which have very low draining capabilities. Therefore, the soil and the vodose zone would be able to hold water and contaminants will be prevented from seeping into the aquifer media. Natural attenuation process may occur during the retention of water and contaminants in the soil and the vadose zone depending on the type of contaminant introduced. There would be in general, a very low net recharge which is the carrier of most contaminants into groundwater. Hence "Very Low" and "Low" vulnerability classes occurring.

The granites are massive, crystalline and impervious and therefore have a very low primary porosity. Aquifers within the granites produce water because of the fractures and weathering. The weathering product of the granites is mostly sand which has a very high draining capability. The soil and the vadose zone would allow more water with contaminants to seep into the aquifer media. This indicates a high net recharge in these zones and is highly vulnerable as net recharge is the carrier of most contaminants into groundwater. The high draining abilities of the soil and the vadose zone, high net recharge couple with low slope percentages and shallow depths of boreholes drilled in the granites are responsible for the vulnerable zones of "Moderate", "High" and "Very High".
The porosity of the fresh phyllites is higher than fresh granites because fractures are more pronounced in the phyllites due to its foliation properties than the massive crystalline texture of the fresh granites. Fracture size decreases with depth due to the effect of the weight of overlying rocks. Also carbonate alterations mostly occur in the phyllites than in the granites resulting in the rapid circulation of groundwater to create cavities for water conduits (Perrouty et al., 2012).

\section{Conclusions}

The DRASTIC Index (DI) or the Vulnerability Index computed ranged between 70 and 164. The groundwater vulnerability to contamination map produced showed five vulnerability classes of "Very Low", "Low", "Moderate" "High" and "Very High".

The vulnerability zones characterised by "Very High", "High" and "Moderate" classes could be located in the eastern and western flanks and northwest tip of KMA. These three vulnerability classes constitute $42.64 \%$ of the total area of KMA and occurred in the granites. These classes that are more susceptible to groundwater contamination because of the high draining capability of sand which is the weathering product of the granites. In general, boreholes drilled in the granite would be highly susceptible to contamination than those in the phyllites which has silt and clay as weathering products making them less vulnerable.

The GIS technique has provided an efficient environment for analysing the data obtained which catches the eye than a simple DI format and has high capabilities in handling large quantities of spatial data.

\section{References}

Anon. (2012), "Annual Average Rainfall Chart between 1980 and 2012: Ghana Meteorological Agency, Kumasi, 10 pp.

Anon. (2010), "Population of KMA", Population and Housing Census of Ghana, Statistical Service Department, 15 pp.

Anon. (1999), "Peri-Urban Interface Production System Research", Inception Report R7330, Peri-Urban Natural Resources Management at the Watershed Level, Kumasi, Ghana, CEDAR Report, Royal Holloway, University of London, $6 \mathrm{pp}$.

Cornish, G. A. and Aidoo, J. B. (1999)," Informal irrigation in the Peri-Urban Zone of Kumasi, Ghana: OD/TN 97, HR, Wallingford, UK, 86 pp.

Dickson, K. B. and Benneh, G. (1988), A new Geography of Ghana, Longman, Glasgow, 170 pp. 
Fetter, C. W. (1994), Applied Hydrogeology, Macmillan College Publishing Company, New York, NY, 615 pp.

Gogo, J. O. (1990), "Geological and Geotechnical Evaluation of Latosols from Ghana and their Environment for Construction", Unpublished MSc Thesis Report, Vrije University, Brussels, Belgium, 209 pp.

Holland, M. D., Kasenga, R. K., Lewcock, C. P. and Warburton, H. J. (1996)," Peri- Urban Baseline Studies, Kumasi, Ashanti Region, Ghana", NRI No. 11, pp. 61-90.

Kesse, G. O. (1985), The Mineral and Rock Resources of Ghana, A. A. BalkemaPublishers, Rotterdam, $610 \mathrm{pp}$.

Kuma, J. S. Y., Owusu, O. R. and Gawu, S. K. Y. (2010), "Evaluating the Water Supply System in Kumasi, Ghana". European Journal of Scientific Research, ISSN 1450-216X, Vol. 40, No 4, pp. 506-514.

Murray, R. J., Mason, D. and Immy, B. C., (1960), "Geology of Kumasi", Geological Survey Field Sheet 26.

Nsiah-Gyabaa, K. (2000), "Characteristics of PeriUrban Villages", Paper presented at the Final Workshop of Kumasi Natural Resources Management Project (R6799), Kumasi, 5 pp.

Perrouty, S., Aillères L., Jessell, M., W., Baratoux, L., Bourassa, Y. and Crawford B., (2012), "Revised Eburnean geodynamic evolution of the gold-rich southern Ashanti Belt, Ghana, with new field and geophysical evidence of pre-Tarkwaian deformations", Precambrian Research, 204-205, pp. 12-39

\section{Authors}

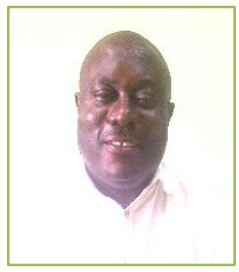

A. Ewusi holds PhD (Groundwater Geophysics), MSc. (Environmental Resource Management) from the Brandenburg University of Technology, Germany and BSc. (Geological Engineering) from the Kwame Nkrumah University of Science and Technology (KNUST), Kumasi, Ghana. He has postqualification experiences in Groundwater Exploration and Environmental Management in Germany, UK, Sierra Leone and Ghana. He has been instrumental in the application of advanced geophysical methods for groundwater exploration in Ghana. He is currently a Lecturer in Geophysics and Hydrogeology at the University of Mines and Technology (UMaT).

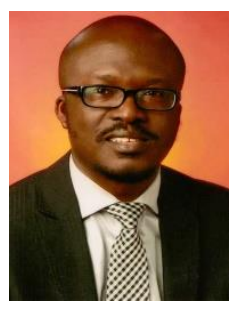

A. Asante-Annor is a lecturer at the Geological Engineering Department at the University of Mines and Technology, Tarkwa. He holds BSc (Hons) in Geological Engineering from the Kwame Nkrumah University of Science and Technology (KNUST), Kumasi, Ghana. $\mathrm{He}$ also holds MSc in Environmental Resources Management and a $\mathrm{PhD}$ in Environmental Engineering from Brandenburg Technical University, Germany. His areas of research include EIA, EMS, groundwater regulations and policies, groundwater resources management and protection. $\mathrm{He}$ is a member of the International Association of Hydrogeologists.

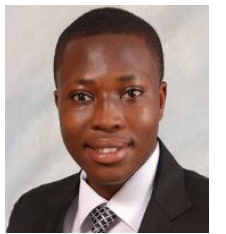

J. Seidu is an MPhil student and a Demonstrator at the Department of Geological Engineering in the University of Mines and Technology. He holds BSc degree in .Geological Engineering from the University of Mines and Technology, Ghana.

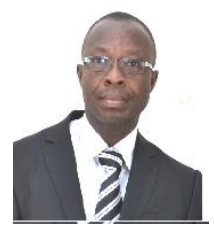

L. O. Fosu-Gyeabour holds MSc in Geological Engineering from the University of Mines and Technology. He has more than fifteen years experience in Mineral Exploration and has worked for many mining companies in Ghana. $\mathrm{He}$ is currently an associate consultant to Ankrah and Associate Limited. 